\title{
Inheritance of Testicular Feminization Syndrome: Some Negative Linkage Findings
}

\author{
RUTH SANGER, PATRICIA TIPPETT, JUNE GAVIN, ANN GOOCH, and \\ R. R. RACE
}

From Medical Research Council Blood Group Research Unit, The Lister Institute, Chelsea Bridge Road, London S.W.1

Testicular feminization is a rare condition: estimates of the incidence vary from 1 in 20,000 to 1 in 130,000 births. Those affected show a normal female physique and orientation: however, they have a short vagina but no uterus, and their gonads are testes which are to be found in the abdomen or in the inguinal canal. The karyotype is male, $\mathrm{XY}$ (Jacobs et al., 1959).

Testicular feminization is clearly inherited, though the exact manner of inheritance is in doubt: it could be an X-linked recessive character or an autosomal dominant character which is expressed only in males (Grumbach and Barr, 1958). Other $\mathrm{XY}$ intersexual conditions with similar patterns of inheritance, such as male pseudohermaphroditism or X-linked hypospadias, are not included in this report.

\section{Linkage Tests}

Hopes were that linkage tests might decide the manner of inheritance: measurable linkage between testicular feminization and an X-borne marker such as colour blindness or the $\mathrm{Xg}$ groups would establish $\mathrm{X}$-linkage; measurable linkage with an autosomal marker would establish the autosomal alternative. With this in view the Blood Group Research Unit was, during the past six years, sent samples of blood from 49 propositi and 170 of their relatives, but no positive result has emerged. If the $t f$ locus be on the $\mathrm{X}$ it is too far away from $X g$ for linkage to be measured. If $t f$ be on an autosome the data are enough to show that it is not close to the loci for ABO, MNSs, Rh, Duffy, or Kidd. Slimmer data are just enough to show that $t f$ is not very close to the loci for P, Lutheran, Kell, Dombrock, or secretor.

The sums of the lod scores (Maynard-Smith, Penrose, and Smith, 1961) are given in the Table.

Received March 21, 1968.
Families were scored only when there was evidence of the condition in the sibs or ancestry of the mother of the propositus or, failing this, when the propositus had an affected sib. A single affected member in a family may represent a new mutation and being so could give no linkage information.

Some of the families have already been published (McKusick, 1962; Philip and Sele, 1965; Boczkowski, 1968; Bartlett et al., 1968) and others probably will be.

The distribution of the $\mathrm{Xg}$ groups among the 49 phenotypically female propositi is, as expected, that of males:

\begin{tabular}{c|c|c|c}
\hline & Observed & $\begin{array}{c}\text { Male } \\
\text { Expectation }\end{array}$ & $\begin{array}{c}\text { Female } \\
\text { Expectation }\end{array}$ \\
\cline { 2 - 3 } $\mathbf{X g}(\mathrm{a}+)$ & 26 & $\begin{array}{c}32.29 \\
\mathbf{X} \cdot 71\end{array}$ & $\begin{array}{r}43.32 \\
5.68\end{array}$ \\
\hline
\end{tabular}

Indeed the $\mathrm{Xg}$ distribution is somewhat ultra-male ( $\chi^{2}$ for 1 d.f. $=3 \cdot 6, \mathrm{p}=1$ in 17 ), but we suppose this to be a chance of sampling and will be surprised, not to say nonplussed, if the tendency persists: the deviation from the female distribution is beyond question ( $\chi^{2}$ for 1 d.f. $=59 \cdot 7, p=1$ in many millions).

So far, linkage tests using blood groups as markers

TABLE

TESTICULAR FEMINIZATION: LINKAGE ANALYSIS

\begin{tabular}{|c|c|c|c|c|c|c|}
\hline & \multirow{2}{*}{$\begin{array}{c}\text { No. of } \\
\text { Scoring } \\
\text { Families }\end{array}$} & \multicolumn{5}{|c|}{ Recombination Fraction, $\theta$} \\
\hline & & 0.05 & $0 \cdot 1$ & $0 \cdot 2$ & $0 \cdot 3$ & $0 \cdot 4$ \\
\hline $\begin{array}{l}\text { Xg } \\
\text { ABO } \\
\text { MNSs } \\
\text { P } \\
\text { Rh } \\
\text { Lutheran } \\
\text { Kell } \\
\text { Secretor } \\
\text { Duffy } \\
\text { Kidd } \\
\text { Dombrock }\end{array}$ & $\begin{array}{r}13 \\
8 \\
12 \\
1 \\
11 \\
1 \\
1 \\
1 \\
11 \\
5 \\
2\end{array}$ & $\begin{array}{l}-4.885 \\
-7.199 \\
-3.849 \\
-0.584 \\
-4.554 \\
-0.536 \\
-0.721 \\
-0.584 \\
-3.807 \\
-1.093 \\
-0.051\end{array}$ & $\begin{array}{l}-2.320 \\
-4.231 \\
-1.728 \\
-0.340 \\
-2.545 \\
-0.305 \\
-0.444 \\
-0.340 \\
-2.075 \\
-0.396 \\
+0.122\end{array}$ & $\begin{array}{l}-0.471 \\
-1.642 \\
-0.221 \\
-0.138 \\
-0.944 \\
-0.121 \\
-0.194 \\
-0.138 \\
-0.730 \\
+0.074 \\
+0.175\end{array}$ & $\begin{array}{l}+0.036 \\
-0.502 \\
+0.147 \\
-0.052 \\
-0.348 \\
-0.045 \\
-0.076 \\
-0.052 \\
-0.261 \\
+0.153 \\
+0.115\end{array}$ & $\begin{array}{l}+0.082 \\
-0.026 \\
+0.116 \\
-0.012 \\
-0.111 \\
-0.010 \\
-0.018 \\
-0.012 \\
-0.090 \\
+0.092 \\
+0.037\end{array}$ \\
\hline
\end{tabular}


leave the problem of the precise manner of inheritance of testicular feminization where it was. However, the recent interpretation by McKusick (1967) of a family reported by Gayral et al. (1960) makes $\mathrm{X}$-linkage look the better guess.

\section{Summary}

Those with the syndrome of testicular feminization are to outward appearance females but their karyotype is $\mathrm{XY}$. The condition is inherited through the mother, but it is not clear whether the gene responsible is X-linked or is autosomal and only able to express itself in the male.

Demonstrable linkage with the X-borne blood group $\mathrm{Xg}$ or with an autosomal blood group would settle the question one way or the other. However, tests on a series of families give no hint of linkage either with $\mathrm{Xg}$ or with the autosomal blood groups, so the problem remains as it was.

The distribution of the $\mathrm{Xg}$ groups in 49 propositi is, as expected, that of males.

The substance of this paper is entirely due to the following physicians and cytogeneticists who, with the linkage problem in mind, sent samples of blood from cases of testicular feminization and from their relatives: Dr. A. Adam of Tel Hashomer, Dr. C. N. Armstrong of Newcastle, Dr. L. Aubert of Toulon, Dr. K. Boczkowski of Warsaw, Dr. C. O. Carter of London, Dr. A. de la Chapelle of Helsinki, Prof. J. H. Edwards of Birmingham, Dr. M. A. Ferguson-Smith of Glasgow, Dr. A. Frøland of Copenhagen, Dr. J. Gray of Newcastle, Dr. J. Leisti of Helsinki, Dr. J. Lindsten of Stockholm, Dr. V. McKusick of Baltimore, Prof. L. S. Penrose of London, Dr. J. Philip of Copenhagen, Prof. P. E. Polani of London, Dr. A. C. Stevenson of Oxford, and Prof. A. C. Turnbull of Cardiff.

\section{RBFERBNCES}

Bartlett, D. J., Grant, J. K., Pugh, M. A., and Aherne, W. (1968). A familiar feminizing syndrome. A family showing intersex characteristics with $\mathrm{XY}$ chromosomes in three female members. 7. Obstet. Gynaec. Brit. Cwlth, 75199.

Boczkowski, K. (1968). Genetical studies in testicular feminization syndrome. F. med. Genet., 5, 181.

Gayral, L., Barraud, M., Carrie, J., and Candebat, L. (1960). Pseudo-hermaphrodisme à type de 'testicule feminisant': II cas. Étude hormonale et étude psychologique. Toulouse méd., 61, 637. (Cited by McKusick, 1967.)

Grumbach, M. M., and Barr, M. L. (1958). Cytologic tests of chromosomal sex in relation to sexual anomalies in man. Recent Progr. Hormone Res., 14, 255.

Jacobs, P. A., Baikie, A. G., Court Brown, W. M., Forrest, H., Roy, J. R., Stewart, J. S. S., and Lennox, B. (1959). Chromosomal sex in the syndrome of testicular feminisation. Lancet, 2, 591.

Maynard-Smith, S., Penrose, L. S., and Smith, C. A. B. (1961). Mathematical Tables for Research Workers in Human Genetics. Churchill, London.

McKusick, V. A. (1962). On the X chromosome of man. Quart. Rev. Biol., 37, 69.

(1967). Mendelian Inheritance in Man, p. 278. Heinemann Medical, London.

Philip, J., and Sele, V. (1965). Testicular feminization. (Karytopic-linkage and endocrine studies in three sibs with the complete syndrome.) Acta endocr. (Kbh.), 48, 297. 